\title{
ANALISIS EFEKTIVITAS SISTEM PENGENDALIAN INTERNAL DENGAN PROTEKSI BANJAR DINAS UNTUK MENCEGAH KREDIT MACET PADA BUMDES KARYA SARI DESA PAKISAN KECAMATAN KUBUTAMBAHAN
}

\author{
Luh Lestari ${ }^{1}$, Lulup Endah Tripalupi ${ }^{2}$, Iyus Akhmad Haris ${ }^{3}$ \\ Jurusan Pendidikan Ekonomi \\ Universitas Pendidikan Ganesha \\ Singaraja, Indonesia \\ e-mail:liilalestari0893@gmail.com¹, lulup_tripalupi@yahoo.com², \\ iyus.haris@gmail.com ${ }^{3}$
}

\begin{abstract}
Abstrak
Penelitian ini bertujuan untuk mengetahui sistem pengendalian internal dan efektivitas sistem pengendalian internal dengan proteksi banjar dinas dalam mencegah kredit macet pada BUMDes Karya Sari desa Pakisan. Jenis penelitian ini merupakan penelitian deskriptif kualitatif. Data dikumpulkan dengan metode wawancara dan dokumentasi dengan menggunakan analisis kualitatif. Hasil penelitian menunjukkan bahwa sistem pengendalian internal pada BUMDes Karya Sari cukup baik. Hal ini dilihat dari analisis kelima unsur sistem pengendalian internal dimulai dari lingkungan pengendalian, aktivitas pengendalian, penaksiran risiko, informasi dan komunikasi, dan pengawasan kinerja. Sedangkan efektivitas sistem pengendalian internal dengan proteksi banjar dinas dalam mencegah kredit macet cukup efektif dengan rata-rata persentase sebesar $86,83 \%$.
\end{abstract}

Kata kunci: banjar dinas, BUMDes, efektivitas, sistem pengendalian internal.

\begin{abstract}
This study aims to determine the internal control system and effectiveness of internal control system with banjar dinas protection in preventing bad loans at the village-owned enterprises of Karya Sari at Pakisan village. This type of research is qualitative descriptive research. Data was collected by interview and documentation method using qualitative analysis. The results showed that the internal control system on village-owned enterprises of Karya Sari is good enough. This is seen from the analysis of the five elements of the internal control system starting from the control environment, control activities, risk assessment, information and communication, and supervision of performance. While the effectiveness of internal control system with banjar dinas protection in preventing bad loans is quite effective with the average percentage of $86.83 \%$.
\end{abstract}

Keywords: banjar dinas, village-owned enterprises, effectiveness, internal control system

\section{PENDAHULUAN}

Pemerintah Provinsi Bali telah melakukan beberapa upaya melalui strategi dan kebijakan dalam peningkatan kesejahteraan dan pengurangan kemiskinan. Hal tersebut tertuang dalam visi Program Bali Mandara Jilid II, yang dijabarkan lebih lanjut dalam Dokumen Strategi Penanggulangan Kemiskinan Daerah (SPKD). Sejalan dengan kebijakan 
tersebut, sejak tahun 2012, Pemerintah Provinsi Bali mengembangkan Program/Kegiatan Gerakan Pembangunan Desa Terpadu Mandara/Gerbang Sadu Mandara menjadi wadah bersama masyarakat pedesaan dalam membangun diri dan lingkungannya secara mandiri dan partisipatif.

Pengendalian internal adalah seperangkat kebijakan dan prosedur untuk melindungi asset dan kekayaan perusahaan dari segala bentuk tindakan penyalahgunaan, menjamin tersedianya informasi akuntansi yang akurat dan memadai, serta memastikan seluruh ketentuan hukum dan kebijakan manajemen telah dipatuhi sebagaimana mestinya oleh setiap karyawan.

Menurut (Johnshon, 2003 : 373), "sistem pengendalian internal mempunyai ruang lingkup yang sangat luas, tidak saja mencakup kegiatan akuntansi dan keuangan, tetapi sangat luas sampai pada setiap aspek operasi perusahaan". Sedangkan menurut Mulyadi (2001), sistem pengendalian intern meliputi struktur organisasi, metode dan ukuran-ukuran yang dikoordinasi untuk menjaga kekayaan organisasi, mengecek ketelitian dan keandalan data akuntansi, mendorong efisiensi dan mendorong dipatuhinya kebijakan manajemen.

Menurut (Halim, 2001:197), bahwa, "struktur pengendalian internal adalah rangkaian proses yang dijalankan entitas, yang mana proses tersebut mencangkup kebijakan dan prosedur sistematis, bervariasi dan memiliki tujuan utama". Dengan adanya sistem pengendalian intern, membuat segala aktivitas dapat dikontrol dengan baik karena sistem pengendalian intern merupakan kebijakan dan struktur sebagai tambahan terhadap pengendalian sistem akuntansi yang telah diciptakan oleh manajemen dengan keyakinan bahwa tujuan perusahaan akan tercapai. Oleh karena itu, BUMDes Karya Sari harus merancang sistem pengendalian internal dalam memberikan kredit.

Menurut Committee of Sponsoring Organizations (COSO) "pengendalian internal diartikan sebagai suatu sistem, struktur atau proses yang diimplementasikan oleh dewan direktur perusahaan, manajemen dan personil lainnya, yang didesain untuk menghasilkan penilaian rasional sebagai upaya mencapai sasaran pengendalian serta memberikan jaminan yang wajar" (Husein, 2005: 121). Lima komponen dalam model pengendalian cosO (Committee of Sponsoring Organizations) adalah lingkungan pengendalian, aktivitas pengendalian, penaksiran resiko, informasi dan komunikasi, serta pengawasan (Diana dan Setiawati, 2011).

Menurut Handoko (2000) efektivitas merupakan hubungan antara output dengan tujuan, semakin besar kontribusi (sumbangan) output terhadap pencapaian tujuan, maka semakin efektif organisasi, program atau kegiatan. Efektivitas berfokus pada outcome (hasil), program, atau kegiatan yang dinilai efektif apabila output yang dihasilkan dapat memenuhi tujuan yang diharapkan. Efektivitas berfokus pada outcome (hasil), program, atau kegiatan yang dinilai efektif apabila output yang dihasilkan dapat memenuhi tujuan yang diharapkan. Menurut Kurniawan (2005: 109) efektivitas adalah kemampuan melaksanakan tugas, fungsi (operasi kegiatan program atau misi) dari pada suatu organisasi atau sejenisnya yang tidak adanya tekanan atau ketegangan diantara pelaksanaanya. Berdasarkan penjelasan diatas maka dapat disimpulkan bahwa efektivitas adalah ukuran yang menyatakan seberapa jauh target atau sasaran yang telah dicapai dalam suatu program, kegiatan atau organisasi.

Efektivitas akan mengukur rasio keberhasilan sistem pengendalian internal yang diterapkan pada BUMDes Karya Sari dalam mencegah kredit macet. Semakin besar rasionya, maka akan semakin efektif sistem pengendalian internal yang diterapkan. Standar minimal resiko keberhasilan adalah $90 \%-100 \%$.

Menurut UU No. 6 Tahun 2014 tentang desa, Pasal 67 bab VI, desa berhak mengatur dan mengurus kepentingan masyarakat berdasarkan hak asal-usul, adat istiadat, dan nilai sosial budaya masyarakat desa. Badan Usaha Milik Desa (BUMDes) adalah lembaga usaha desa 
yang dikelola oleh masyarakat dan pemerintahan desa, dalam upaya memperkuat perekonomian desa dan dibentuk berdasarkan kebutuhan dan potensi desa. BUMDes merupakan suatu lembaga keuangan yang mana tujuannya utamanya adalah untuk memberikan pinjaman kredit kepada masyarakat yang membutuhkan untuk menjalankan suatu usahanya. Selain itu, BUMDes juga bisa mendirikan usaha-usaha untuk meningkatkan ekonomi masyarakat desa. Oleh karena itu, keberadaan BUMDes diharapkan mampu menstimulasi dan menggerakkan roda perekonomian desa.

Dinyatakan di dalam undang-undang bahwa BUMDes dapat didirikan sesuai dengan kebutuhan dan potensi desa. Apa yang dimaksud dengan "kebutuhan dan potensi desa" adalah kebutuhan masyarakat terutama dalam hal pemenuhan kebutuhan pokok; tersedia sumberdaya desa yang belum dimanfaatkan secara optimal terutama kekayaan desa dan terdapat permintaan dipasar; tersedia sumber daya manusia yang mampu mengelola badan usaha sebagai asset penggerak perekonomian masyarakat, serta adanya unit-unit usaha yang merupakan kegiatan ekonomi warga masyarakat yang dikelola secara parsial dan kurang terakomodasi (Pusat Kajian Dinamika Sistem Pembangunan, 2007).

BUMDes Karya Sari merupakan suatu badan usaha yang ada di Desa Pakisan yang dikelola oleh masyarakat dan pemerintah desa, dalam upaya memperkuat perekonomian desa dan dibentuk berdasarkan kebutuhan dan potensi desa. Sumber modal dari BUMDes Karya Sari berasal dari setengah dana Gerbang Sadu Mandara. Tujuan utama dari program Gerbang Sadu Mandara adalah untuk mengentaskan kemiskinan ditingkat pedesaan. Pada BUMDes Karya Sari hanya mampu mempunyai satu unit usaha yaitu usaha simpan pinjam. Hal ini disebabkan karena keterbatasan tempat dan lokasi BUMDes yang kurang strategis untuk membuka unit usaha lain. Sejalan dengan tujuan dari adanya BUMDes yaitu untuk mengentaskan kemiskinan, maka yang menjadi target atau sasaran dari pemberian kredit adalah masyarakat miskin, sehingga masyarakat miskin mendapat modal dan memiliki peluang untuk membuka usaha sendiri. BUMDes Karya Sari merupakan salah satu asset dan sumber pendapatan desa sehingga memerlukan pengelolaan yang baik oleh pengurus dan badan pengawas. Pengawasan kredit yang memadai, baik secara internal maupun eksternal perlu dimilki oleh BUMDes guna mencegah terjadinya penyalahgunaan wewenang oleh berbagai pihak dan praktikpraktik keuangan yang dapat mempengaruhi kesehatan BUMDes. Pemberian kredit merupakan kegiatan utama dari BUMDes Karya Sari yang mengandung resiko paling tinggi dan dapat mempengaruhi kesehatan dan kelangsungan dari BUMDes Karya Sari. "Setiap lembaga yang memberikan fasilitas kredit harus melaksanakan pengawasan dan pengendalian terhadap pemberian kredit" (Hery, 2014:66). Salah satu resiko yang paling sering terjadi dalam pemberian kredit adalah adanya kredit bermasalah atau kredit macet. Untuk menghindari adanya kredit macet, sangat diperlukan adanya pengendalian internal kredit dengan maksud dapat menjaga pengelolaan kekayaan organisasi, mengecek ketelitian dan dapat mendorong efisiensi untuk mematuhi kebijakan manajemen.

Berkaca dari pengalaman setiap lembaga perkreditan Desa Pakisan yang selalu mengalami pasang surut dalam permodalan akibat banyaknya permasalahan kredit macet, pengelolaan BUMDes Karya Sari hendaknya harus mempertimbangkan terlebih dahulu seluk beluk tentang nasabahnya. Pertimbangan tersebut didasarkan atas penilaian yang dilakukan karena pemberian kredit merupakan salah satu kegiatan usaha yang memiliki tingkat resiko yang sangat tinggi terhadap kesehatan BUMDes. Sering terjadi kredit macet dalam perkreditan Desa Pakisan diakibatkan oleh sikap dari masyarakat sendiri yang kurang kooperatif dan hanya menuntut hak saja.

Untuk mengamankan pinjaman, penyertaan jaminan sangatlah penting dalam pemberian kredit. Namun dalam praktiknya, BUMDes Karya Sari tidak 
mensyaratkan adanya jaminan dalam pemberian kredit, mengingat tujuan BUMDes sendiri untuk mengentaskan kemiskinan. Calon debitor hanya perlu melengkapi administrasi dan menyetujui surat perjanjian kredit. Hal ini menjadikan BUMDes Karya Sari sangat riskan terhadap adanya risiko kredit macet, bahkan kredit bermasalah dengan menjadikan nasabah kurang bertanggungjawab dalam membayar kreditnya. Dalam surat perjanjian kredit tersebut hanya diatur mengenai sanksi sanksi yang akan diberikan jika terlambat membayar ataupun tidak membayar angsuran pinjaman. Adapun jenis sanksi tersebut meliputi pengenaan denda dan sanksi adat dan dinas (tidak mendapat pelayanan di banjar adat dan dinas serta bantuan sosial lainya). Untuk mencegah terjadinya kredit macet, BUMDes Karya Sari melibatkan peran banjar Dinas. Untuk mengatasi permasalahan tersebut, banjar adat yang ada di Desa Pakisan dengan sepakat bersama pemerintah desa bersama-sama berkomitmen untuk mendukung BUMDes dengan memberikan proteksi bagi BUMDes Karya Sari dalam menghadapi permasalahan kredit macet dengan membuat aturan-aturan yang mengikat.

Menurut Surpha (2012), banjar adalah kelompok masyarakat yang lebih kecil dari desa adat dan menjadi bagian dari desa adat serta merupakan persekutuan hidup sosial, baik dalam keadaan senang maupun susah. Banjar Dinas adalah organisasi pemerintah di desa yang menyelenggarakan fungsi administratif, seperti mengurus kartu tanda penduduk, dan lain-lain persoalan kedinasan (pemerintahan).

Dengan melibatkan keberadaan banjar dinas, pengelolaan BUMDes Karya Sari sangat yakin bisa mencegah terjadinya kredit macet meskipun dalam pemberian kreditnya tidak mensyaratkan collateral atau jaminan kepada debitor. Berdasarkan permasalahan tersebut, terlihat seperti keefektifan dalam mencegah kredit macet dengan melibatkan banjar dinas. Oleh sebab itu, peneliti tertarik untuk melakukan penelitian pada BUMDes Karya Sari dengan mengambil judul penelitian : "
Analisis Efektivitas Sistem Pengendalian Internal dengan Proteksi Banjar Dinas dalam Mencegah Kredit Macet pada Badan Usaha Milik Desa (BUMDes) Karya Sari di Desa Pakisan"

\section{METODE}

Penelitian ini termasuk dalam jenis penelitian deskriptif kualitatif. Penelitian ini dilakukan di BUMDes Karya Sari mengenai analisis sistem pengendalian internal dengan proteksi banjar dinas dalam mencegah kredit macet pada Metode pengumpulan data yang digunakan dalam penelitian ini adalah metode wawancara, dan dokumentasi. Subjek penelitian adalah Ketua dan karyawan BUMDes Karya Sari serta Kepala Desa Pakisan. Sedangkan objek penelitian adalah BUMDes Karya Sari. BUMDes Karya Sari Desa Pakisan, Kecamatan Kubutambahan. Jenis data yang digunakan dalam penelitian ini berupa data primer dan data sekunder.

Efektivitas adalah suatu ukuran keberhasilan atau kegagalan dari informasi dalam mencapai suatu tujuan. Efektivitas digunakan untuk mengukur tingkat kolektabilitas kredit dengan tujuan atau target yang telah ditetapkan pada BUMDes Karya Sari. Dalam penelitian ini yang diukur efektivitasnya adalah besarnya target kredit tertagih dengan besarnya kredit terealisasi.

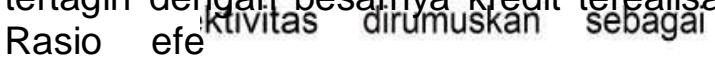
berikut.

$$
\begin{array}{r}
\text { Rasio Efektivitas }= \\
\frac{\text { Realisasi kredit tertagih }}{\text { Target kredit tertagih }} \times 100 \%
\end{array}
$$

Berikut ini disajikan tablel kriteria rasio efektivitas.

Tabel 1. Kriteria rasio efektivitas

\begin{tabular}{ll}
$\begin{array}{l}\text { Presentase } \\
\text { Efektivitas }\end{array}$ & Kriteria \\
\hline$>100 \%$ & Sangat Efektif \\
$90-100 \%$ & Efektif \\
$80-89 \%$ & Cukup Efektif \\
$60-79 \%$ & Kurang Efektif \\
$<60 \%$ & Tidak Efektif \\
\hline
\end{tabular}

HASIL DAN PEMBAHASAN 
Sistem pengendalian internal dengan proteksi banjar dinas dalam mencegah kredit macet pada BUMDes Karya Sari sudah dilakukan dengan cukup optimal. Hal ini dapat dilihat dari hasil wawancara yang telah dilakukan oleh peneliti dengan pihak BUMDes dilihat dari unsur-unsur sistem pengendalian internal yang telah diterapkan. Dilihat dari hasil evaluasi unsurunsur sistem pengendalian yang sudah dilakukan oleh pihak BUMDes itu sendiri. Dimulai dari Lingkungan pengendalian yang sudah cukup baik. Hal ini dapat dilihat dari filosofi manajemen, Dilihat dari filosofi manajemen dan gaya operasi, manajemen bertanggung jawab untuk menyusun kode etik perusahaan dan memperlakukan setiap karyawan dengan adil dan dengan hormat. Pada BUMDes Karya Sari, ketua BUMDes yang menjalankan peran sebagai manajer selalu memberikan contoh perilaku etis kepada karyawannya. Beliau selalu datang tepat waktu dan tegas dalam setiap pengambilan keputusannya. Setiap karyawan diperlakukan secara adil dan hormat tanpa membedakan gender dan status dari karyawan. Para karyawan ditekankan agar selalu ramah dalam melayani nasabah. Meskipun BUMDes Karya Sari tidak memiliki kode etik yang disusun secara tertulis, ketua dan karyawanya senantiasa untuk selalu menjaga nama baik BUMDes Karya Sari dengan memberikan pelayanan yang optimal terhadap masyarakat Desa Pakisan.

Komitmen terhadap integritas dan nilai etika dapat dilihat dari kemampuan manajemen untuk menciptakan budaya organisasi yang menekankan pada integritas dan nilai-nilai etika. Perilaku etis atau tidak etis manajer dan karyawan berdampak besar terhadap keseluruhan pengendalian internal. Hal ini sudah diterapkan oleh BUMDes Karya Sari dengan melihat budaya organisasi yang cukup baik. Dapat dilihat dari tindakan ketua BUMDes yang proaktif untuk memastikan bahwa semua karyawannya benar-benar sadar akan standar perilaku yang etis dengan memberikan teguran kepada karyawan yang menunjukkan tanda-tanda perilaku tidak etis, misalnya karyawan yang terlambat datang, maupun karyawan yang kurang fokus terhadap pekerjaannya. Ketua BUMDes juga selalu mengambil keputusan dengan berpegang pada nilai-nilai etika meskipun menghadapi keputusan yang sulit. Komitmen terhadap kompetensi pada suatu organisasi dapat dilihat dari bagaimana manajemen dalam merekrut karyawan yang kompeten dan dapat dipercaya guna mendorong kreatifitas dan inisiatif dalam menghadapi kondisi yang dinamis.

Pada BUMDes Karya Sari komiten terhadap kompetensi ini sudah dilakukan dengan cukup baik. Hal ini dapat dilihat dari perekrutan karyawan yang dilakukan langsung oleh Kepala Desa Pakisan. Kepala Desa Pakisan tidak menyalahgunakan wewenangnya dengan merekrut sembarang orang. Komitmen terhadap Dewan direksi bertanggung jawab untuk memilih komite audit yang beranggotakan orang-orang dari luar perusahaan. Tugas komite audit adalah memantau akuntansi perusahaan serta praktik dan kebijakan laporan keuangan.

Pendamping yang merupakan pihak dari luar Desa Pakisan ditunjuk langsung dari pihak Gubernur. Pendamping bertugas untuk mendampingi dan mengawasi praktik-praktik akuntansi pada BUMDes Karya Sari. Pendamping merupakan tangan kanan dari pemerintah Provinsi Bali yang bertugas untuk mengirim laporan keuangan fisik langsung kepada Pemerintah Provinsi Bali. Selain itu, pendamping juga memberikan solusi-solusi atas masalahmasalah yang dihadapi oleh BUMDes Karya Sari. BUMDes Karya Sari sudah memiliki struktur organisasi yang jelas dengan pembagian tugas yang sudah jelas juga. Tugas dan wewenang tersebut tertuang dalam Peraturan Desa Pakisan, Kecamatan Kubutambahan, Kabupaten Buleleng No 4 Tahun 2012 tentang Pembentukan Badan Usaha Milik Desa (BUMDes) Desa Pakisan. Kebijakan dan praktik sumber daya manusia meliputi perekrutan karyawan baru, orientasi karyawan baru, pelatihan karyawan, motivasi karyawan, evaluasi karyawan, promosi karyawan, kompensasi karyawan, perlindungan karyawan, dan pemberhentian 
karyawan. BUMDes Karya Sari sudah melaksanakan kebijakan dan praktik sumber daya tersebut dengan optimal. Hal tersebut dibuktikan pada manajemen BUMDes dengan mengikuti petunjuk teknis pelaksanaan BUMDes dari Pemerintah Provinsi Bali, yaitu dengan merekrut karyawan sesuai dengan jumlah minimal. Jumlah minimal karyawan termasuk ketua adalah empat orang, terdiri dari dua perempuan dan dua laki-laki. BUMDes Karya Sari mengambil jumlah minimal tersebut untuk meningkatkan kesejahteraan karyawan karena gaji yang didapatkan karyawan sebesar $25 \%$ dari laba operasional BUMDes Karya Sari, dimana $25 \%$ dari laba tersebut akan dibagi sebanyak jumlah karyawan dengan porsi sesuai dengan jabatan tanggung jawabnya. Karyawan juga dipastikan bekerja dalam lingkungan kerja yang aman dan sehat dengan dibuatkannya sebuah kantor yang nyaman untuk operasional BUMDes Karya Sari.

Aktivitas pengendalian pada BUMDes Karya Sari sudah tergolong optimal, hal ini dapat dilihat dari setiap dokumen yang dikeluarkan sudah berisi nomor urut cetak sebagai wujud pertanggung jawaban penggunaan dokumen, terdapat pemisahan tugas untuk mengurangi peluang karyawan melakukan pencurian harta dan setiap transaksi langsung diotorisasi oleh ketua BUMDes. Ketiga adalah penaksiran risiko. Meskipun penaksiran risiko yang dilakukan oleh pihak BUMDes belum optimal, akan tetapi ketua dan karyawan BUMDes berusaha untuk meminimalisasi agar tidak terjadi kredit macet. Selanjutnya untuk informasi dan komunikasi, BUMDes Karya Sari selalu menginformasikan dan mengkomunikasikan laporan keuangannya kepada Kepala Desa Pakisan dan seluruh elemen masyarakat desa Pakisan.

BUMDes Karya Sari tidak menjurnal setiap transaksi yang ada melainkan hanya mencatat secara sederhana pada list angsuran, drop pinjaman ataupun drop bulanan. Dari data tersebut akan dibuatkan laporan berupa neraca. Setiap akhir periode, BUMDes Karya Sari akan menginformasikan laba yang diperoleh dan membagikan sisa hasil usaha kepada masing-masing banjar dinas dan pemerintah desa. Pengawasan kinerja karyawan dilakukan oleh ketua BUMDes, yaitu dengan memperhatikan cara kerja karyawanya kemudian mengevaluasi serta mengoreksinya. Supervisi tidak dilakukan secara optimal karena BUMDes Karya Sari telah memiliki pemisahan tugas yang jelas serta karyawan BUMDes Karya Sari memiliki kesadaran penuh akan tugastugasnya dan selalu menjunjung tinggi nilainilai etika dalam organisasi BUMDes. Akuntansi pertanggung jawaban BUMDes Karya Sari dilakukan dengan dua cara, yaitu dengan mengupload laporan keuangannya ke website Gerbang Sadu Mandara dan memberikan laporan keuangan kepada pendamping untuk diberikan kepada Pemerintah Provinsi Bali.

Sistem pemberian kredit kepada para calon nasabah pada BUMDes Karya Sari masih tergolong sangat sederhana. Prosedur pemberian kredit diawali dengan kedatangan calon nasabah ke BUMDes Karya Sari yaitu bagian administrasi untuk meminta Surat Permohonan Pinjaman (SPP). SPP ini berisikan informasi mengenai identitas calon nasabah dan penanggung, rencana penggunaan dana, sumber penghasilan atau pengembalian, serta jaminan kredit. Data mengenai jaminan kredit akan dikosongkan karena sampai saat ini, semua kredit yang diberikan oleh BUMDes Karya Sari masih belum menggunakan jaminan dengan maksud agar tidak memberatkan calon nasabah. Hal ini berkaitan dengan tujuan utama dari BUMDes untuk memberantas kemiskinan di Desa Pakisan. Surat permohonan pinjaman akan diotorisasi oleh kelian banjar yang bersangkutan, Kepala Desa, dan Ketua BUMDes. Disetujui atau tidaknya kredit yang diajukan bergantung pada kelian banjar dan kepala Desa. Kelian banjar akan menganalisis karakter calon debitur berdasarkan kehidupan keseharian mereka dan kebiasaan calon debitur di banjar dinas. Apabila calon debitur tidak memiliki sangkutan utang piutang di banjar dinas, maka surat permohonan kreditnya akan disetujui dan ditandatangani. Setelah kelian banjar dinas menyetujuinya, SPP akan diteruskan kepada kepala Desa untuk 
dianalisis kelayakannya. Jika calon debitur merupakan orang yang rajin bekerja, memiliki karakter yang baik di mata masyarakat, dan tidak suka berjudi, maka kepala Desa akan menandatangani Surat Permohonan Pinjaman calon debitur. Selanjutnya calon debitur akan memberikan SPP tersebut kepada Ketua BUMDes untuk ditandatangani. Ketua BUMDes akan menugaskan sekretaris untuk mencetak Surat Perjanjian Kredit.

Tahap selanjutnya adalah mengisi Surat Perjanjian Kredit (SPK) dengan Ketua BUMDes sebagai pihak I (pertama) dan peminjam serta penanggungnya menjadi pihak II (kedua). Dalam SPK ini dicantumkan beberapa ketentuan, yaitu BUMDes Karya Sari memberikan tambahan modal kerja untuk melaksanakan usaha dengan syarat-syarat yang telah ditentukan. Surat perjanjian kredit ini diotorisasi oleh Ketua BUMDes dan juga menyertakan tanda tangan dari pihak II yaitu peminjam dan penanggungnya. Selanjutnya bendahara akan mengeluarkan kwitansi pengeluaran kredit sebesar jumlah kredit yang disetujui sebanyak satu rangkap untuk diarsip oleh BUMDes Karya Sari. Bagian
Administrasi/Rekap akan mencatat transaksi pada Drop Pinjaman di Komputer sedangkan bagian kasir/bendahara mencatat transaksi pada Drop Pinjaman secara manual. Kemudian debitur akan menerima uang sebesar jumlah kredit yang disetujui dan debitur akan diberikan sebuah Kartu Angsuran untuk mencatat pembayaran kredit setiap bulannya. Saat pembayaran, debitur mendatangi kantor BUMDes Karya Sari dengan membawa kartu angsuran kemudian bendahara dan staf administrasi masing-masing akan mencatat pembayaran tersebut pada drop bulanan secara manual dan di komputer.

Efektivitas sistem pengendalian internal dengan proteksi banjar adat dalam mencegah adanya kredit macet pada BUMDes Karya Sari akan dinilai dengan membandingkan realisasi kredit dengan target kredit tertagih. Tingkat efektivitas dapat diketahui dengan melakukan perhitungan rasio efektivitas, suatu usaha dikatakan efektif apabila proses kegiatan mencapai tujuan dan sasaran akhir kebijakan. Ringkasan target kredit pokok dan realisasi kredit pokok serta analisis ekektivitasnya dapat dilihat pada tabel 2 .

Tabel 2. Ringkasan list angsuran bulanan BUMDes Karya Sari per Maret 2017 (dalam rupiah)

\begin{tabular}{|c|c|c|c|c|}
\hline Banjar Adat & $\begin{array}{l}\text { Target Kredit Pokok } \\
\text { Tertagih } \\
\text { (Rp) }\end{array}$ & $\begin{array}{l}\text { Realisasi Kredit } \\
\text { pokok } \\
(\mathrm{Rp})\end{array}$ & Persentase & Kategori \\
\hline Kelandis & $\operatorname{Rp} 16,120,000$ & $\operatorname{Rp} 11,768,000$ & $87.02 \%$ & Cukup Efektif \\
\hline Mengandang & Rp $11,630,000$ & $\operatorname{Rp} 9,740,000$ & $83.84 \%$ & Cukup Efektif \\
\hline Pakisan & $\operatorname{Rp} 51,514,000$ & Rp 44,226,000 & $85.85 \%$ & Cukup Efektif \\
\hline Tegehe & $\operatorname{Rp} 66,556,000$ & $\operatorname{Rp} 59,487,000$ & $89.37 \%$ & Cukup Efektif \\
\hline Sangburni & Rp 26,968,000 & Rp 24,796,000 & $91.94 \%$ & Efektif \\
\hline Total Presentase & Rp $172,788,000$ & $\operatorname{Rp} 150,017,000$ & $86.83 \%$ & Cukup Efektif \\
\hline
\end{tabular}

Hasil penelitian menunjukkan bahwa pada Banjar Dinas Kelandis, BUMDes Karya Sari menargetkan pokok kredit tertagih sebesar Rp. 16.120.000. Dari target tersebut pada Banjar Dinas Kelandis, realisasi kredit pokok sebesar $\mathrm{Rp}$. 11.768.000. Setelah dihitung dengan analisis efektivitas didapatkan hasil yang menunjukkan tingkat efektivitas mencapai $87,02 \%$. Berdasarkan kriteria penelitian efektivitas yang dipakai acuan peneliti, 
dapat dikatakan bahwa pada Dusun Kelandis efektivitas sistem pengendalian internal dengan proteksi banjar dinas dalam kriteria cukup efektif, karena tingkat efektivitasnya pada kisaran 80 - 89\%.

Pada Banjar Dinas Mengandang, BUMDes Karya Sari menargetkan pokok kredit tertagih sebesar Rp. 11.630.000. Dari target tersebut pada Banjar Dinas Mengandang, realisasi kredit pokok sebesar Rp. 9.740.000. Setelah dihitung dengan analisis efektivitas didapatkan hasil yang menunjukkan tingkat efektivitas mencapai 83,34 \%. Berdasarkan kriteria penelitian efektivitas yang dipakai acuan peneliti, dapat dikatakan bahwa pada Banjar Dinas Mengandang efektivitas sistem pengendalian internal dengan proteksi banjar dinas dalam kriteria cukup efektif, karena tingkat efektivitasnya pada kisaran dibawah 80 - 89\%. Pada Banjar Dinas Pakisan, BUMDes Karya Sari menargetkan pokok kredit tertagih sebesar Rp. 51.514.000. Dari target tersebut pada Banjar Dinas Pakisan, realisasi kredit pokok sebesar Rp. 44.226.000. Setelah dihitung dengan analisis efektivitas didapatkan hasil yang menunjukkan tingkat efektivitas mencapai $85,85 \%$. Berdasarkan kriteria penelitian efektivitas yang dipakai acuan peneliti, dapat dikatakan bahwa pada Banjar Dinas Pakisan efektivitas sistem pengendalian internal dengan proteksi banjar dinas dalam kriteria cukup efektif, karena tingkat efektivitasnya pada kisaran dibawah 80 - 89\%.

Pada Banjar Dinas Tegehe, BUMDes Karya Sari menargetkan pokok kredit tertagih sebesar Rp. 66.566.000. Dari target tersebut pada Banjar Dinas Pakisan, realisasi kredit pokok sebesar $\mathrm{Rp}$. 59.487.000. Setelah dihitung dengan analisis efektivitas didapatkan hasil yang menunjukkan tingkat efektivitas mencapai $89,87 \%$. Berdasarkan kriteria penelitian efektivitas yang dipakai acuan peneliti, dapat dikatakan bahwa pada Banjar Dinas Tegehe efektivitas sistem pengendalian internal dengan proteksi banjar dinas dalam kriteria cukup efektif, karena tingkat efektivitasnya pada kisaran dibawah 80 $89 \%$.

Pada Banjar Dinas Sangburni,
BUMDes Karya sari menargetkan pokok kredit tertagih sebesar Rp. 26.968.000. Dari target tersebut pada Banjar Dinas Sangburni, realisasi kredit pokok sebesar Rp. 24.796.000. Setelah dihitung dengan analisis efektivitas didapatkan hasil yang menunjukkan tingkat efektivitas mencapai $91,94 \%$. Berdasarkan kriteria penelitian efektivitas yang dipakai acuan peneliti, dapat dikatakan bahwa pada Banjar Dinas Sangburni efektivitas sistem pengendalian internal dengan proteksi banjar dinas dalam kriteria efektif, karena tingkat efektivitasnya pada kisaran dibawah 90 $-100 \%$.

\section{Pembahasan}

Dari hasil penelitian yang telah dilakukan melalui metode wawancara, BUMDes Karya Sari sudah melaksanakan sistem pengendalian internal dengan baik. Hal ini dapat dilihat dari hasil evaluasi unsur-unsur sistem pengendalian yang sudah dilakukan oleh pihak BUMDes itu sendiri. Dimulai dari lingkungan pengendalian yang sudah cukup baik. Hal ini dapat dilihat dari filosofi manajemen, komitmen terhadap nilai-nilai etika dan gaya operasi, komitmen terhadap kompetensi, struktur organisasi dan integritas dari Kepala BUMDes dan karyawannya yang sudah berusaha untuk memberikan pelayanan yang maksimal kepada masyarakat desa Pakisan untuk kenyaman dan kelancaran aktivitas BUMDes Karya Sari. Kemudian dilihat dari aktivitas pengendalian pada BUMDes Karya Sari sudah tergolong optimal, hal ini dapat dilihat dari setiap dokumen yang dikeluarkan sudah berisi nomor urut cetak sebagai wujud pertanggung jawaban penggunaan dokumen, terdapat pemisahan tugas untuk mengurangi peluang karyawan melakukan pencurian harta dan setiap transaksi langsung diotorisasi oleh ketua BUMDes. Ketiga adalah penaksiran risiko. Meskipun penaksiran risiko yang dilakukan oleh pihak BUMDes belum optimal, akan tetapi ketua dan karyawan BUMDes berusaha untuk meminimalisasi agar tidak terjadi kredit macet. Selanjutnya untuk informasi dan komunikasi, BUMDes Karya Sari melaporkan laporan keuangannya setiap 
bulan beserta masalah dan hambatan yang dihadapi dengan pihak pemerintah desa Pakisan. Kemudian yang terakhir adalah pengawasan kinerja. Pengawasan kinerja karyawan dilakukan oleh ketua BUMDes, yaitu dengan memperhatikan cara kerja karyawanya kemudian mengevaluasi serta mengoreksinya. Supervisi tidak dilakukan secara optimal karena BUMDes Karya Sari telah memiliki pemisahan tugas yang jelas serta karyawan BUMDes Karya Sari memiliki kesadaran penuh akan tugastugasnya.

Sistem pemberian kredit kepada para calon nasabah pada BUMDes Karya Sari masih tergolong sangat sederhana. Diawali dengan kedatangan calon nasabah ke BUMDes Karya Sari dengan membawa persyaratan yang telah ditentukan. Kemudian calon nasabah meminta Surat Permohonan Pinjaman (SPP) pada bagian administrasi. Setelah SPP yang diajukan disetujui oleh Kepala BUMDes Karya Sari, calon nasabah diwajibkan untuk mengisi Surat Perjanjian Kredit (SPK). Surat perjanjian kredit ini diotorisasi oleh Ketua BUMDes dan juga menyertakan tanda tangan dari pihak II yaitu peminjam dan penanggungnya. Selanjutnya bendahara akan mengeluarkan kwitansi pengeluaran kredit sebesar jumlah kredit yang disetujui sebanyak satu rangkap untuk diarsip oleh BUMDes Karya Sari.

Berdasarkan penelitian yang telah dilakukan penulis melalui metode dokumentasi, proteksi dari banjar dinas sudah cukup efektif dalam mencegah kredit macet. Efektifitas sistem pengendalian internal dengan proteksi banjar dinas sudah dalam kategori cukup efektif dilihat dari perbandingan target pokok kredit dengan realisasi pokok kredit. Meskipun tidak ada tingkat efektivitas berada dalam tingkat sangat efektif atau berada dalam angka $100 \%$, hal ini disebabkan karena kurang maksimalnya komunikasi dan kerjasama antar pegawai BUMDes dengan pemeritah desa dan kelian banjar adat dalam memberikan pelayanan terhadap para debitur. Sanksi yang telah disepakati terkadang dilanggar sendiri oleh pemerintah desa dan kelian banjar yang bersangkutan karena timbulnya rasa kasihan terhadap para debitur. Adapun persentase tingkat efektifitas target kredit tertagih dengan realisasi kredit pada lima banjar adat yang ada di Desa Paksian ialah, Dusun Kelandis $(87,02 \%)$, Dusun Mengandang (83.84\%), Dusun Pakisan (85.85\%), Dusun Tegehe (89.37\%), dan Dusun Sangburni (91.94\%).

\section{SIMPULAN DAN SARAN}

Berdasarkan hasil penelitian yang telah dilakukan pada BUMDes Karya Sari Desa Pakisan, Kecamatan Kubutambahan, dapat disimpulkan bahwa sistem pengendalian internal pada BUMDes Karya Sari dikatakan cukup baik, karena BUMDes Karya Sari telah memiliki lingkungan pengendalian yang baik, yaitu ketua BUMDes yang memiliki fungsi sebagai manajer mampu memberikan contoh budaya organisasi yang baik serta berkomitmen terhadap kompetensi kerjanya. BUMDes Karya Sari sudah memiliki struktur organisasi, penetapan otorisasi, dan pemisahan tugas yang jelas serta kebijakan praktik sumber daya manusia dalam merekrut karyawannya. Dokumen yang digunakan dalam pemberian kredit cukup memadai. Efektivitas sistem pengendalian internal dengan proteksi banjar dinas dalam mencegah kredit macet pada BUMDes Karya Sari terbukti cukup efektif, karena dari total kredit per Maret 2017 sebesar Rp.322.805.000. Sedangkan yang termasuk dalam kategori kredit bermasalah sebesar Rp.172.788.000 dari total kredit dengan rasio total persentase efektivitas mencapai 87,39\%. Dari jumlah kredit bermasalah tersebut, tidak terdapat kredit yang termasuk kredit macet, melainkan kredit kurang lancar dan kredit diragukan saja.

Temuan ini sejalan dengan teori efektivitas yang disebutkan oleh Mardiasmo (2002:134) efektivitas adalah ukuran berhasil tidaknya suatu organisasi mencapai tujuannya, walaupun dengan biaya yang lebih besar karena disini efektivitasnya hanya melihat apakah suatu program atau kegiatan telah mencapai tujuan yang telah ditetapkan. Efektifitas merupakan salah satu kriteria yang digunakan untuk menilai prestasi kerja 
suatu pusat pertanggung jawaban tertentu. Efektifitas merupakan kemampuan untuk memilih tujuan yang tepat atau peralatan yang tepat untuk mencapai tujuan yang telah ditetapkan, menyangkut bagaimana melakukan pekerjaan yang benar.

\section{Saran}

Berdasarkan simpulan yang diperoleh dari hasil penelitian ini, maka dapat dikemukakan beberapa saran yaitu, Penerapan sistem pengendalian internal pada BUMDes Karya Sari agar tetap di pertahankan dan lebih di tingkatkan supaya proses manajemen pada BUMDes dapat berjalan dengan lancar dan untuk penaksiran risiko dalam meminimalisir kredit bermasalah yang masih kurang optimal sebaiknya dibuatkan cadangan kerugian piutang supaya bisa menutup kerugian piutang yang tidak tertagih dan proses penyaluran kredit bisa berjalan lancar.

Dalam pemberian kreditnya, pihak BUMDes bersama dengan pemerintah desa dan prajuru banjar adat agar bisa memberikan pengawasan dan pembinaan terhadap usaha yang dimiliki oleh debitur RTM, sehingga usaha dari debitur ini berjalan lancar dan debitur mampu membayar kewajibannya di BUMDes Karya Sari secara tepat waktu. Bagi peneliti selanjutnya diharapkan mampu mengembangkan pembahasan lebih mendalam tentang penerapan sistem pengendalian internal agar lebih meningkatkan generalisasi penelitian.

\section{DAFTAR PUSTAKA}

Agung, Kurniawan. 2005. Transformasi Pelayanan Publik. Yogyakarta: BPFE.

Diana, Anastasia \& Lilis Setiawati. 2011. Sistem Informasi Akuntansi. Yogyakarta: Andi.

Halim, Abdul. 2001. Auditing Dasar - Dasar Audit Laporan Keuangan. Jilid I Edisi Revisi. Yogyakarta: Universitas Gajah Mada.

Handoko, Hani. 2000. Manajemen Personalia dan Sumber Daya
Manusia. Edisi II. Cetakan Keempat Belas. Yogyakarta: BPFE.

Hery. 2014. Pengendalian Akuntansi Manajemen. Jakarta: PT Fajar Interpratama Mandiri.

Husein, Umar. 2005. Metode Penelitian Untuk Skripsi dan Tesis Bisnis. Jakarta: Grafindo Persada.

Johson, Boyton. 2003. Modern Auditing. Jilid I. Edisi Ketujuh. Jakarta: Erlangga.

Mardiasmo. 2002. Akuntansi Sektor Publik. Yogyakarta: Andi.

Mulyadi. 2001. Sistem Akuntansi. Edisi Ketiga. Jakarta: Salemba Empat. Presiden Republik Indonesia. 2014. Undang - Undang Republik Indonesia No 6 Tahun 2014 Tentang Desa. Jakarta.

Pusat Kajian Dinamika Sistem Pembangunan. 2007. Buku Paduan Pendirian dan Pengelolaan Badan Usaha Milik Desa (BUMDes). Departemen Pendidikan Nasional: PP-RPDN.

Surpha, I Wayan. 2012. Seputar Desa Pakeraman dan Adat Bali. Denpasar: PT. Offset BP Denpasar. 